IN VIVO BONE MINERAL CONTENT IN SICKLE CELL ANEMIA. Charles H. Epps, Jr., Jay R. Shapiro, W. Tabb Moore and Hildegard Jorgensen, (Intr. by Roland B. Scott), Division of Orthopaedic Surgery and Center for Sickle Cell Anemia at Howard University and Washington Hospital Center, Washington, D.c.

Bone Mineral Content (BMC) was determined by the photon absorption method of Cameron and Sorenson in 58 black children (33 females and 25 males) with confirmed sickle cell anemia (SS). Bone scans were performed through the mid-radius (cortical bone) using 125-iodine as a monochromatic source of photons. Data is expressed both as $\mathrm{GM} / \mathrm{cm}$ scanned or as the ratio of BMC to bone width (BMC/BW). The values obtained in these patients were compared to values in normal black and white children. BMC in normal black and white children showed what appeared to be a linear increase with age. In accordance with the data of Trotter, et al, we found that radius BMC is higher in black than in white at all ages, although accuracy and precision are less below the age of two. $64 \%$ of males and $39 \%$ of females with sickle cell disease have less BMC than normal black children of the same age (less than $95 \%$ confidence limits). The ratio $\mathrm{BMC} / \mathrm{BW}$ as related to age follows the normal pattern indicating similar reduction in $\mathrm{BMC}$ and $\mathrm{BW}$ in affected children. The factors contributing to the sex difference as regards the mineralization are not clear. Severity of anemia and transfusion need are considered as possible factors determining the extent of mineral loss.
CORRELATION OF TRANSFERIN (Tf) LEVELS IN NEWBORN PLASMA WITH BIRTHWEIGHT AND GESTATIONAL AGE (GA). S. Galet ${ }^{+}$, H.M. Schulman and H. Bard. McGill Univ. Dept. B1ol. Lady Davis Inst. Jewish Gen. Hosp, and Univ. of Montreal, Dept. of Ped, SteJustine Hosp., Montrea1, Canada.

Recent studies on the function of If have suggested that along with its role in the control of Iron metabolism it also has a inhibitory effect on bacterlal growth. Plasma Tf concentrations were determined in newborn infants of various $\mathrm{GA}$ at birth and postnatally using the radial immunodiffusion method. 140 determinations were made on 50 infants and the results were correlated with the GA, birthweight and postnatal age. At birth term, appropriate in weight for GA (AGA) infants had the same Tf level $1 \mathrm{~s}(2.1 \mathrm{mg} / \mathrm{m} 1-\mathrm{SE} 0.17 \mathrm{mg} / \mathrm{m} 1)$ as healthy adults $(2.03 \mathrm{mg} / \mathrm{m} 1-\mathrm{SE} 0.17 \mathrm{mg} / \mathrm{ml})$. A significantly reduced level of Tf was found in term small for GA infants $(1.47 \mathrm{mg} / \mathrm{m} 1$ - SE $0.11 \mathrm{mg} / \mathrm{m} 1, \mathrm{P}<.001)$. The lowest levels of Tf were found in the Preterm (PR)AGA infants $(1.26 \mathrm{mg} / \mathrm{ml} \pm$ $\mathrm{SE} 0.10 \mathrm{mg} / \mathrm{ml} ; \mathrm{P}<.001)$. There was a correlation between increased $T f$ and $G A$ in the PRAGA infants $(R=0.659, P<.001)$. The PRAGA infants born at less than 32 weeks of GA required 6-8 weeks to achieve normal term levels. Early PRAGA infants may be at a physiological disadvantage in respect to both iron metabolism and their resistance to bacterial infection due to a prolonged period of low levels of plasma Tf.
LEUKEMIC BLASTS WITH MEMBRANE CHARACTERISTICS OF EITHER T OR B CELLS. John M. Falletta, Nalini Mukhopadhyay, Kenneth A. Starling, and Dona1d J. Fernbach (Intr. by L. Leighton Hili). Baylor Co1. of Med., Dept. of Ped., Houston.

Blasts obtained from the diagnostic bone marrow aspiration in 13 children with acute leukemia (excluding acute granulocytic leukemia) were examined for $T$ and $B$ cell membrane characteristics. Blasts accounted for $70-98 \%$ (median $92 \%$ ) of the nucleated cells obtained. Cells were harvested using a sodium metrizoate/Ficoll gradient. Membrane characteristics were assessed by the overnight formation of spontaneous sheep erythrocyte rosettes at $4^{\circ} \mathrm{C}$ ( $\mathrm{T}$ cells), and by the presence of membrane-bound immunoglobulin ( $\mathrm{Ig}$ ) and $\mathrm{C}^{\prime} 3$ receptors (B cells).

Two children had blasts ( 41 and $79 \%$ ) which reacted as $T$ cells. Two other children had blasts ( 31 and $80 \% *)$ which resembled $B$ cells. In the remaining 9 children, over $92 \%$ of the cells reacted as neither $T$ nor $B$ cells.

In 1 child (noted above*) following relapse, $82 \%$ of the nucleated cells were blasts; $96 \%$ of the cells had detectable surface Ig with $80 \%$ IgG positive, $5 \%$ IgA positive, and $11 \%$ IgM positive. C' 3 receptors were detected on $31 \%$ of the cells by direct immunofluorescence and on $28 \%$ by immune rosette formation using complement and antibody-coated erythrocytes.

These data illustrate the heterogeneity of the leukemic cells in children with acute leukemia. A minority of these children have blasts with a cell membrane differentiated enough to bear receptors similar to either $T$ or $B$ cells.

\section{A NEW APPROACH TO THE DESIGN OF EFFECTIVE TREATMENT FOR NEURO-} BLASTOMA. Jerry $Z$. Finklestein, Karen L. Tittle, Frank M. Hirose, Hideo Itabashi, Andrew Mitchel1, John Weiner, UCIA \& USC Schools of Med., Harbor Gen. Hosp., Depts. of Ped. \& Path. and the Biostat. Unit, USC Medical Center, Torrance, Calif.

The reliability of the $\mathrm{Cl} 300$ murine neuroblastoma system was evaluated as a screening model for new apprasches to the treatment of the childhood disease. Histopathologic and electron microscopic cytochemical studies showed the presence of catecholamine-like granules within cytoplasmic extensions; this supports the neural origin of the neoplasm. Tumor cell kinetic evaluations demonstrated a doubling time in vivo of 1.3 days and an autoradiographic study of the generation time in vivo revealed a Ts:Tc ratio of 0.38 . Drug toxicity and chemotherapy trials were conducted in $\mathrm{A} / \mathrm{J}$ mice using three different regimens of antitumor agents (single, daily and intermittent). The known effectiveness of various schedules of cyclophosphamide in humans were reproduced in animals with palpable disease. Adriamycin, guanazole and cytosine arabinoside were identified as agents of potential activity for children with neuroblastoma. Bleonycin, 5-azacytidine, 5-fluorouracil, bleomycin-vincristine combination and 6-hydroxydopamine therapy were inactive in the doses and regimens used.

The usual animal tumor systems have not been helpful in the design of clinical trials for children. The biological properties of the murine neuroblastoma model suggest that it may identify effective drug regimens for patients with widespread disease.
A REVALUATION OF ASPIRIN (ASA) INDUCED HEMOLYSIS ASSOCIATED WITH ERYTHROCYTE GLUCOSE-6-PHOSPHATE DEHYDROGENASE (G6PD) DEFICIENCY. Bertil E. Glader (Intr. by Herbert Schwartz), Department of Pediatrics, Harvard Medical School, Children's Hospital Medical Center, Boston, Mass. 02115

ASA has been implicated as a causative hemolytic agent in some individuals with G6PD deficiency. Gentisic acid (GA), the one known oxidant metabolite of salicylate, stimulated the hexosemonophosphate (HMP) shunt of normal RBC's. This effect, however, was seen at GA concentrations greater than $2 \mathrm{mM}$ (equivalent to a minimum salicylate level of $20 \mathrm{mM}$ or $350 \mathrm{mg}$ ). At thexapeutic salicylate concentrations of $2 \mathrm{mM}$ (35 mg8) and/or with $0.2 \mathrm{mM} \mathrm{GA}$, no effect on the resting or ascorbate-stimulated HMP shunt was noted. G6PD deficient RBC's incubated with $0.2 \mathrm{mM} \mathrm{GA}$ and/or $2.0 \mathrm{mM}$ salicylate manifested no significant sulfhemoglobin formation or glutathione oxidation. Noninfected, afebrile G6PD deficient Black males given ASA ( $50 \mathrm{mg} / \mathrm{kg} /$ day $\times 4$ days) had no significant changes in hemoglobin, hematocrit, reticulocytes or bilirubin. These studies suggest it is unlikely that therapeutic doses of ASA would be hemolytic in Black G6PD deficient patients. Most cases of ASA-associated hemolysis more probably are related to the reason the drug is given (ie, infection) rather than the drug per se. Instead of arbitrarily excluding this useful drug from G6PD deficient individuals, a similar ASA tolerance test done under close observation would seem a more reasonable approach for detecting ASA sensitivity.

EFFECT OF ELEVATED GLUCOSE CONCENTRATIONS ON THE OXIDANT SENSITIVITY OF GLUCOSE-6-PHOSPHATE DEHYDROGENASE (G6PD) DEFICIENT ERYTHROCYTES. Bertil E. Glader (Intr. by Herbert Schwartz), Department of Pediatrics, Harvard Medical School, Children's Hospital Medical Center, Boston, Mass. 02115

Diabetic acidosis is known to trigger hemolysis in patients with G6PD deficiency. Elevated glucose concentrations activate hexonate dehydrogenase, Oxidize NADPH, and hence stimulate the hexose monophosphate (HMP) shunt. The present studies investigated whether HMP shunt activation, in the presence of increased glucose concentrations, significantly increased the vulnerability of G6PD deficient RBC's to oxidant injury. In normal RBC's, both the resting and ascorbate-stimulated HMP shunt (glucose-1-14 C oxidation to ${ }^{14} \mathrm{CO}_{2}$ ) were greater in 50 than $5 \mathrm{mM}$ glucose. Glutathione regeneration in diamide-treated normal RBC's was the same at 5 and $50 \mathrm{mM}$ glucose. Hydroxylaminedapsone, which requires NADPH for drug activation and maximal hemoglobin oxidation, produced more methemoglobin in normal than G6PD deficient cells but no difference was seen when the effects of 5 and $50 \mathrm{mM}$ glucose were compared. Sulfhemoglobin formation in G6PD deficient RBC's incubated with cyanide and ascorbate was not significantly different in 5 or $50 \mathrm{mM}$ glucose. These data indicate that NADPH-dependent reactions vital for hemoglobin protection are not affected adversely by increased glucose concentrations. Thus, it is unlikely that hyperglycemia significantly alters the reductive potential of G6PD deficient RBC's during an oxidant stress such as infection. 